\title{
Routine 64-slice spiral CT scanning in diagnosis of Thoracic trauma
}

\author{
MENG Fanshan*, LIU Debin, CUI Xuefeng \\ From 2012 PLA Emergency Medicine Annual Congress \\ Beijing, China. 9-12 November 2012
}

\section{Objective}

To investigate the value of routine 64-slice spiral CT scanning in diagnosis for patients with acute thoracic trauma in emergency room.

\section{Methods}

The clinical data of 268 patients with chest wound who were admitted to our hospital in recent years after 64slice spiral CT scanning and X-ray check were reviewed and analyzed.

\section{Results}

Among these patients with chest wound 206 patients were found distinct injury after CT inspection, but only 108 patients were found injured with X-ray check. The CT scanning results were as follows: lungs were damaged in 148 cases, including 87 with lung contusion, 52 with lacerated wound, and 9 with tracheal bronchial tube damage. Damages outside the lungs were seen in 126 patients, including 56 patients with trauma in pleural membrane (22 cases of hemothorax, 26 cases of pneumothorax and 8 cases of blood pneumothorax), 9 cases with mediastinum damage (5 cases of vertical mediastinal pneumatosis, 4 cases of hematocete), 78 cases with thoracic wall damage (59 cases of rib bone fracture, 19 cases of breastbone fracture).

\section{Conclusion}

CT scanning is a principal way in the diagnosis of chest wound. It has the advantages of quick scanning and the characteristics of high sensitivity, and it will certainly play a vital role in first-aid process in emergency medical treatment of chest wound.

* Correspondence: taianmengmeng88@hotmail.com

Emergency Department, the $88^{\text {th }}$ Hospital of PLA, Taian 271000, Shandong, China

\section{Biomed Central}

Published: 18 December 2012

doi:10.1186/1471-227X-12-S1-A3

Cite this article as: Fanshan et al:: Routine 64-slice spiral CT scanning in diagnosis of Thoracic trauma. BMC Emergency Medicine 2012 12(Suppl 1): A3.
Submit your next manuscript to BioMed Central and take full advantage of:

- Convenient online submission

- Thorough peer review

- No space constraints or color figure charges

- Immediate publication on acceptance

- Inclusion in PubMed, CAS, Scopus and Google Scholar

- Research which is freely available for redistribution

\section{Biomed Central}

